\title{
Pembelajaran Matematika Menggunakan Model Contextual Teaching and Learning (CTL) Pada Materi Kubus Dengan Konteks Tahu di Kelas VIII
}

\author{
Depi Adela Sari, Chika Rahayu, Indah Widyaningrum \\ STKIP Muhammadiyah Pagaralam \\ depiadelasari@gmail.com
}

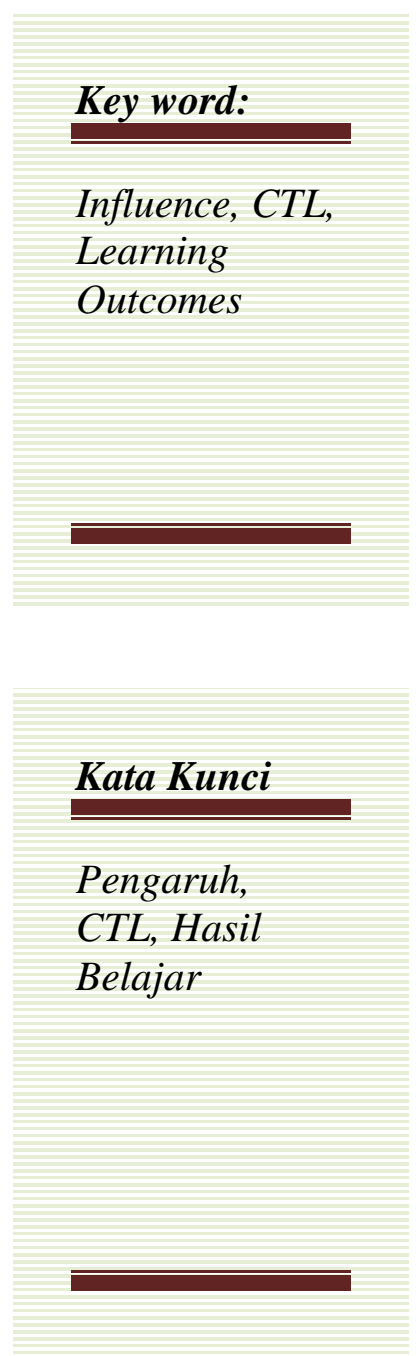

Abstract

This service uses the Pretest Posttest Design design. The purpose of this service is to determine the effect of contextual teaching and learning (CTL) learning models on student learning outcomes on cube material with the context of tofu in grade VIII? Data collection uses documentation and test methods. The data is processed using the t test statistical test. Based on data analysis, the average value of experimental class students is 83.90 and control class 73.11. From the average value obtained by students, it can be seen that mathematics learning using contextual teaching and learning (CTL) learning models with context knows that it has a positive effect on student learning outcomes on cube material.

\section{Abstrak}

Pengabdian ini menggunakan desain Pretest Posttest Design. Tujuan dalam Pengabdian ini adalah untuk mengetahui pengaruh model pembelajaran contextual teaching and learning (CTL) terhadap hasil belajar siswa pada materi kubus dengan konteks tahu di kelas VIII?. Pengumpulan data menggunakan metode dokumentasi dan tes. Data tersebut diolah dengan menggunakan uji statistik uji t. Berdasarkan analisis data maka diperoleh nilai ratarata siswa kelas eksperiment yaitu 83,90 dan kelas kontrol 73,11. Dari nilai rata - rata yang diperoleh siswa, maka dapat terlihat bahwa pembelajaran matematika menggunakan model pembelajaran contextual teaching and learning (CTL) dengan konteks tahu berpengaruh positif terhadap hasil belajar siswa pada materi kubus. 


\section{PENDAHULUAN}

Kubus adalah adalah balok yang semua rusuknya sama panjang, (Gunanto, 2015). Menurut Suprianto (2013), Kubus adalah bangun ruang yang dibatasi 6 buah sisi berbentuk persegi yang ukurannya sama. Sedangkan Mustaqim dan Astuty (2008), berpendapat bahwa kubus adalah sebuah benda ruang yang ditutupi oleh enam buah persegi yang terdiri dari tiga pasang sisi yang berhadapan, yang panjang rusuk tiap pasangan sama dengan pasangan lainnya.

Menurut Ismail (2014), menyatakan bahwa kesulitan siswa dalam belajar kubus adalah guru mengajarkan matematika berdasarkan urutan yang tertulis dalam buku ajar. Guru umumnya mengajar dengan memberi ceramah dan memberi tugas latihan pada siswanya serta mengejar target. Kesulitansiswa pada materi kubus adalah kesulitan menguasai konsep kubus yang terdiri dari kesulitan menyebutkan dan mengajukan unsur-unsur dari kubus pada gambar. Kesulitan memberikan pengertian kubus, kesulitan menemukan rumus volume kubus serta menggunakan rumus volume kubus, (Mutia, 2017).

Dalam Pengabdian (Mutia, 2017), menyatakan Alternatif pemecahan masalah dari kesulitan belajar siswa tersebut yaitu untuk mengatasi kurangya penguasaan konsep kubus dengan menggunakan alat peraga sederhana. Dengan menggunakan alternatif ini diharapkan siswa akan lebih mudah memahami konsep bangun ruang karena diberikan penyajian secara visualisasi dimana unsur-unsur kubus dijelaskan secara konkret melalui gerakan sehingga siswa tidak berimajinasi dengan bentuk-bentuk unsur kubus. Darrwis dan Sugita (2014), mengatakan pemanfaatan alat peraga dalam pembelajaran bangun ruang khususnya pembelajaran volume kubus terkesan bahwa guru lebih banyak mendominasi kegiatan pembelajaran dimana alat peraga dijadikan sebagai alat demonstrasi di dalam kelas, siswa hanya mengamati apa yang dilakukan atau diinformasikan oleh guru.

Kurikulum adalah seperangkat rencana dan pengaturan mengenai isi dan bahan pelajaran serta cara yang digunakan sebagai pedoman penyelenggaraan kegiatan belajar mengajar, (Hamalik, 2008). Kurikulum merupakan kunci utama untuk mencapai sukses atau tidaknya di dalam dunia pendidikan, sama halnya dengan pendapat Poerwati (2013), bahwa kurikulum sangat penting untuk dunia pendidikan karena merupakan kunci utama untuk mencapai sukses dalam ilmu pendidikan. Kurikulum yang sedang berjalan saat ini adalah kurikulum 2013. Dalam kurikulum 2013 siswa dituntut aktif 
dan siswa dapat mengaplikasikan pelajaran kedalam kehidupan sehari-hari terutama dalam pembelajaran matematika, (Fitriyani, 2015).

Pemilihan model pembelajaran yang sesuai dengan tujuan kurikulum 2013 merupakan kemampuan dan keterampilan yang dimiliki oleh seorang guru. Hal ini didasari oleh asumsi bahwa ketepatan guru dalam model pembelajaranakan berpengaruh terhadap hasil belajar siswa. Menurut Suartini (2014), salah satu model pembelajaran yang dapat diimplementasikan adalah model pembelajaran Contextual Teaching And Learning (CTL) dengan berbantuan alat peraga.

Pembelajaran kontekstual merupakan salah satu pembelajaran yang banyak dibicarakan orang-orang. Berbeda dengan strategi-strategi yang telah dibicarakan sebelumnya. Pembelajaran Contextual Teaching And Learning (CTL) adalah konsep belajar yang membantu guru mengaitkan antara materi yang diajarkannya dengan situasi dunia nyata. Hal itu, mendorong siswa membuat hubungan antara pengetahuan yang dimilikinya dengan penerapannya dalam kehidupan sehari-hari. Proses ini melibatkan tujuh komponen utama pembelajaran efektif, yaitu: konstrutivisme (Constructivism), bertanya (Questioning), menemukan (Inquiri), komunitas belajar (Learning Community), pemodelan (Modelling), dan penilaian sebenarnya (Authentic Assessment), ( Aqib, 2015).

Berdasarkan

Pengabdian sebelumnya oleh Laili (2016), menunjukan bahwa pembelajaran matematika dengan model Contextual Teaching And Learning (CTL) dapat meningkatkan kemampuan pemecahan masalah matematika. Usman (2015), mengatakan bahwa penggunaan model pembelajaran Contextual Teaching And Learning (CTL) dapat meningkatkan hasil belajar siswa kelas V SD negeri 35 pekanbaru. Menurut Suartini (2014), menyatakan bahwa terdapat perbedaan yang signifikan keterampilan membaca permulan siswa yang mengikuti pembelajaran Contextual Teaching And Learning (CTL) dengan berbantuan alat peraga kartu huruf dengan siswa yang belajar dengan metode konvensional.

Penerapan model pembelajaran dengan menggunakan alat peraga khususnya bidang studi matematika didasari kenyataan bahwa pada bidang studi matematika terdapat banyak poko bahasan yang menggunakan alat peraga untuk menjabarkannya,diantaranya pada materi bangun ruang dengan pokok bahasan volume kubus. Oleh sebab itu, pelajaran menggunakan alat peraga pada pokok bahasan tersebut dianggap sangat 
tepat untuk membantu mempermudah siswa memahami materi. Disisi lain suasana belajar akan lebih hidup, dan komunikasi antara guru dan siswa dapat terjalin dengan baik. Hal ini diduga pula dapat membantu siswa dalam upaya meningkatkan prestasi belajar belajar pada bidang studi matematika, (Fatimah, 2013).

Berdasarkan penjelasan di atas maka tujuan dalam Pengabdian ini adalah untuk mengetahui Pengaruh Model Pembelajaran Contextual Teaching And Learning (CTL) Terhadap Hasil Belajar siswa Pada Materi Kubus Dengan Konteks Tahu Di Kelas VIII SMP Negeri 1 Muara Pinang Tahun Pelajaran 2017/2018.

\section{METODE PELAKSANAAN}

Pengabdian ini menggunakan metode eksperimen yaitu dengan mengambil dua kelas yaitu kelas kontrol dan kelas eksperimen. Kelas ditentukan cara undian. Kelas eksperimen adalah kelas yang menggunakan model pembelajaran Contextual Teaching And Learning (CTL) dan kelas kontrol adalah kelas yang tidak menggunakan metode ceramah dan tanya jawab, kemudian diberi materi yang sama.

Desain Pretest Posttest Design juga digunakan dalam pengabdian ini. Desain Pengabdian ini digunakan karena Pengabdian ini menggunakan Kelompok Eksperimen dan kelompok kontrol, adanya dua perlakuan yang berbeda, dan pengambilan sampel secara acak kelas. Tes matematika di lakukan dua kali yaitu sebelum pembelajaran (Pre-test) dan sesudah proses pembelajaran (Post-test). Secara singkat desain tersebut digambarkan adalah sebagai berikut.

\section{Tabel 1}

Desain Pengabdian

\begin{tabular}{|llll|}
\hline $\mathrm{E}$ & $\mathrm{O}_{1}$ & $\mathrm{X}$ & $\mathrm{O}_{2}$ \\
$\mathrm{~K}$ & $\mathrm{O}_{3}$ & $\mathrm{X}$ & $\mathrm{O}_{4}$ \\
\hline
\end{tabular}
Keterangan
E: Eskperimen
K: Kontrol
O: Objek

\section{HASIL PEMBAHASAN}

Pembelajaran

matematika

menggunakan Model Pembelajaran Contextual Teaching and Learning (CTL) dengan konteks tahu pada materi volume kubus, yaitu:

1. Guru Membagi siswa dalam beberapa kelompok yang terdiri dari 5-6 siswa dalam setiap kelompok.

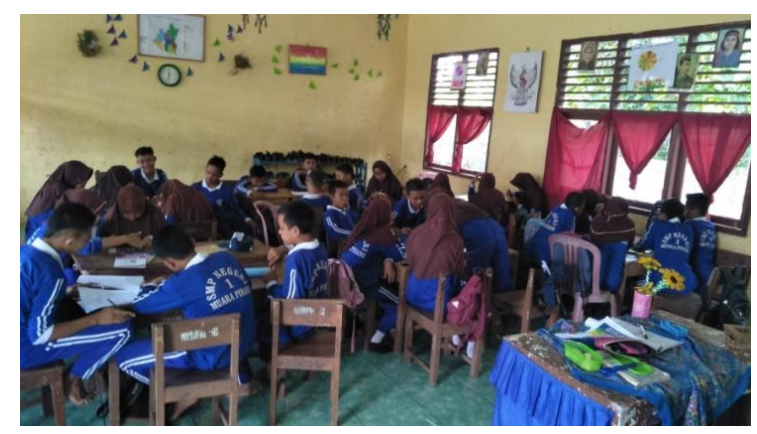

Gambar 1. Pembagian Kelompok

2. Guru membagikan lembar kerja pesrta didik (LKPD) kepada setiap Kelompok 
peserta didik, kemudian meminta peserta didik mengerjakannya kelompoknya masing-masing.

3. Guru berkeliling untuk mengamati, memotivasi, dan memfasilitasi kerja sama, Siswa bekerja dalam kelompok menyelesaikan permasalahan yang diajukan guru

4. Dengan mengacu pada jawaban siswa, melalui tanya jawab, guru dan siswa membahas cara penyelesaian masalah yang tepat,

5. Guru mengadakan refleksi dengan menanyakan kepada siswa tentang halhal yang dirasakan siswa, materi yang belum dipahami dengan baik, kesan dan pesan selama mengikuti pembelajaran.

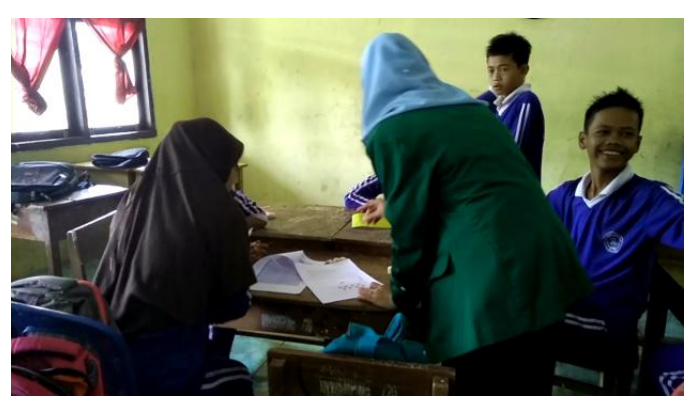

Gambar 2. Mengadakan Refleksi

6. Siswa dalam kelompok menyelesaikan lembar kerja peesrta didik (LKPD) yang diajukan guru.

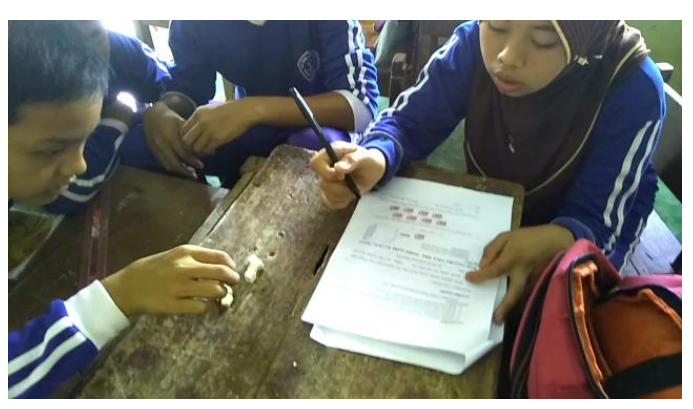

Gambar 3. Siswa Menyelesaikan LKPD

7. Siswa wakil kelompok mempresentasikan hasil kerja kelompok dan kelompok yang lain menanggapi hasil kerja kelompok yang mendapat tugas,

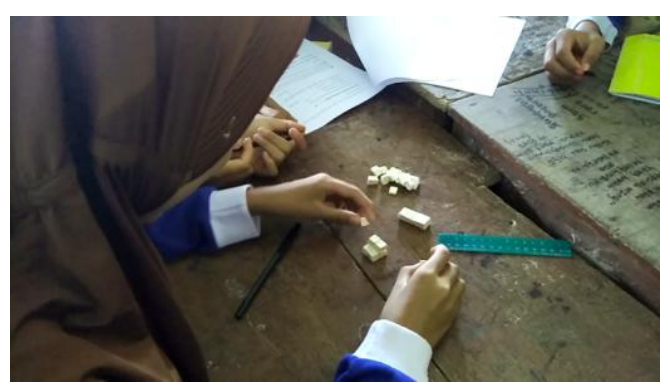

Gambar 4. Mempersentasikan Hasil Kerja Kelompok

8. Guru meminta peserta didik mengamati pekerjaan peserta didik yang sudah ditampilkan, kemudian menyimpulkan hasilnya.

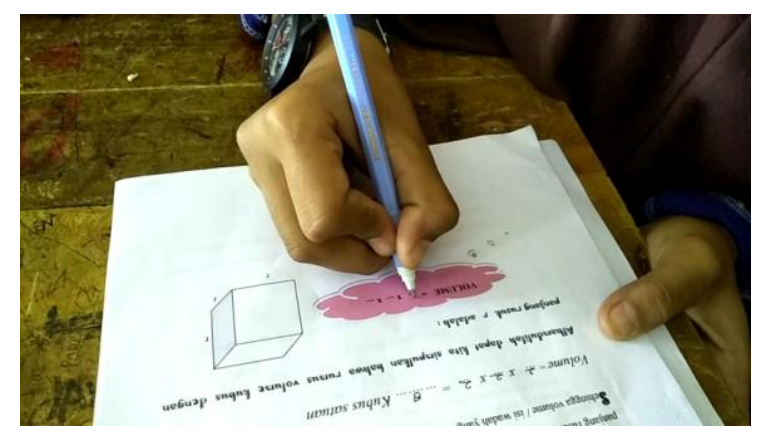

Gambar 5. Kesimpulan Hasil Kerja Kelompok 
Berdasarkan hasil Pengabdian yang dilakukan hasil belajar siswa SMP Negeri 1 Muara Pinang ada perbedaan antara kelas yang diajarkan menggunakan model pembelajaran Contextual Teaching and Learning (CTL) dengan konteks Tahu dengan kelas yang tidak diajarkan menggunakan model pembelajaran Contextual Teaching and Learning (CTL) dengan konteks Tahu, nilai rata-rata siswa lebih baik dibandingkan siswa yang tanpa menggunakan model pembelajaran Contextual Teaching and Learning (CTL) dengan konteks Tahu. Ada pengaruh model pembelajaran Contextual Teaching and Learning (CTL) dengan konteks Tahu terhadap hasil belajar siswa tersebut dapat dilihat dari nilai rata-rata siswa kelas eksperiment yaitu $\underset{x_{1}}{\rightarrow}=83,90$ dan kelas kontrol $\underset{x_{2}}{\overrightarrow{4}}=73,11$. Sehingga hipotesis dalam Pengabdian ini, Ada Pengaruh Model Pembelajaran Contextual Teaching And Learning (CTL) Terhadap Hasil Belajar Siswa Pada Materi Kubus Di Kelas VIII SMP Negeri 1 Muara Pinang Tahun Pelajaran 2017/2018 dan dapat diterima kebanarannya. Hal ini dibuktikan berdasarkan perhitungan statistik hitung $\mathrm{t}_{\text {hitung }}=3,22$ dan $-\mathrm{t}_{\text {tabel }}=1,693$ yang menunjukan $t_{\text {hitung }}>t_{\text {tabel. }}$.

Hal ini disebabkan pembelajaran menggunakan Model Pembelajaran
Contextual Teaching And Learning (CTL)

pada kelas eksperimen dalam proses pembelajaran siswa terlihat antusias dalam belajar, apalagi disini siswa menggunakan konteks yang dekat dengan siswa dalam mempelajari materi volume kubus yaitu menggunakan konteks tahu. Selain itu pada kelas eksperimen ketika siswa menyelesaikan soal dalam bentuk essay dapat lebih sistematis, lebih terampil, teliti dan dapat memberikan kesimpulan dari soal-soal yang diberikan sehingga dapat meningkatkan hail belajar siswa dalam melaksanakan pembelajaran dan sebaliknya siswa pada kelas kontrol yang tanpa menggunakan model pembelajaran Contextual Teaching And Learning (CTL) dan tanpa menggunakan konteks tahu siswa terlihat kurang antusias dalam belajar, siswa hanya menerima saja materi yang diajarkan.

\section{SIMPULAN}

Berdasarkan Pengabdian yang telah dilakukan, maka dapat menyimpulkan bahwa: Dengan menggunakan model pembelajaran Contextual Teaching And Learning (CTL) dalam proses belajar mengajar melihat siswa kelas VIII.D (Kelas Eksperimen) dapat lebih trampil, kritis, dapat lebih memahami soal, dan dapat menyelesaikan soal-soal yang diberikan dengan teliti dibandingkan 
dengan siswa kelas VIII.G (kelas kontrol) yang belajar tanpa menggunakan model pembelajaran Contextual Teaching And Learning (CTL). Dengan menggunakan model pembelajaran Contextual Teaching And Learning (CTL) nilai siswa pada kelas eksperimen lebih besar dibandingkan dengan nilai kelas kontrol dimana dilihat dari nilai rata-rata kelas VIII.D (Kelas Eksperimen) $\overrightarrow{x_{1}}=84,19$ dan rata-rata nilai kelas VIII.G (kelas kontrol) $\overrightarrow{x_{2}}=73,11$. Kriteria perhitungan hipotesis berdasarkan $\mathrm{t}_{\text {hitung }}$ sebesar 3,39 dan $\mathrm{t}_{\text {tabel }}$ sebesar 1,701 menurut kriteria pengujian jika $\mathrm{t}_{\text {hitung }}=3,39$ $>\mathrm{t}_{\text {tabel }}=1,701$ ini berarti $\mathrm{H}_{0}$ ditolak dan $\mathrm{H}_{\mathrm{a}}$ diterima. Sehingga dapat di simpulakan bahwa Model Pembelajaran Contextual Teaching And Learning(CTL) dengan konteks tahu berpengaruh positif terhadap hasil belajar siswa pada materi kubus dengan konteks tahu di Kelas VIII SMP Negeri 1 Muara Pinang Tahun Pelajaran 2017/2018.

\section{SARAN}

Pengabdian ini perlu diujikan kepada sekolah-sekolah lain untuk meningkatkan pemahaman yang baik mengenai kubus dan bangun ruang lainnya.

\section{UCAPAN TERIMAKASIH}

Ucapan rasa terima kasih yang sebesar-besarnya diucapkan kepada SMP
Negeri 1 Muara Pinang, LPPM STKIP Muhammadiyah Pagaralam, dan seluruh siswa yang berpartisipasi dalam pengabdian ini.

\section{DAFTAR PUSTAKA}

Agib, Z. (2015). Model-Model, Media Dan Strategi Pembelajaran Kontekstual. Jakarta: Yrama Widya.

Arikunto, S. (2010).Prosedur Pengabdian Suatu Pendekatan. Jakarta:Rineka Cipta.

Darwis, D., Sugita, G., \& Anggraini, A. Peningkatan Pemahaman Siswa Pada Materi Volume Kubus dan Balok Menggunakan Alat Peraga di Kelas V SDN Pebatae Kecamatan Bumi Raya Kabupaten Morowali. Jurnal Kreatif Tadulako Online, 1(1).

Fatimah, F. (2018). Peningkatan Hasil Belajar Siswa dengan Menggunakan Alat Peraga pada Materi Balok di Kelas V SD Kemala Bhayangkari Banda Aceh. Jurnal Dedikasi Pendidikan, 2(1), 89-96.

Fitriyani, E., Sutama, S., \& Narimo, S. (2016). Pengelolaan Evaluasi Aspek Sosial Dalam Pembelajaran Matematika Kurikulum 2013 di Sekolah Menengah Pertama. Manajemen Pendidikan, 10 (1), 154-161.

Gunanto.(2015). Matematika untuk SD/MI Kelas IV.Jakarta: Erlangga.

Hamalik, O. (2008). Kurikulum dan Pembelajaran. Jakarta: Bumi Aksara. 
Laili, H. (2016). Pengaruh Model Pembelajaran Contextual Teaching and Learning (CTL) Dalam Meningkatkan Kemampuan Pemecahan Masalah Matematika Siswa MTs Nurul Hakim Kediri Ditinjau dari Segi Gender. PALAPA: Jurnal Studi Keislaman dan Ilmu Pendidikan, 4 (2), 34-52.

Ismail, I., Barra'Tandiayuk, M., \& Paloloang, B. (2010). Meningkatkan Hasil Belajar Siswa Pada Materi Konsep Volume Balok Dan Kubus Melalui Pendekatan Kontruktivisme Di Kelas IV SDN 3 Tonggolobibi. Jurnal Kreatif Tadulako Online, 4 (1).

Mustaqin dan Astuti.(2008). Ayo Belajar Matematika.Jakarta: Pusat Perbukuan Departemen Pendidikan Nasional.

Mutia, M. (2017). Analisis kesulitan siswa SMP dalam memahami konsep kubus balok dan alternatif pemecahannya. Beta: Jurnal Tadris Matematika, 10(1), 83-102.

Poerwati. (2013). Panduan Memahami Kurikulum 2013, Sebuah Inovasi Strukrur Kurikulum Penunjang Pendidikan Masa Depan. Jakarta: PT Prestasi Pustakarya.

Suartini, dkk.(2014). Pengaruh Model Pembelajaran Kontekstual
Berbatuan Alat Peraga Kartu Huruf Terhadap Keterampilan Membaca Permulaan Siswa Kelas 1 SD.Jurnal Mimbar PGSD Univesutas Pendidikan Ganesha Volume 1 Nomor 1.

Suprianto. (2013). Matematika Untuk SD/MI Kelas V. Bekasi: Arya Duta.

Usman, R. (2015). Penerapan Metode Contextual Teaching And Learning (CTL)Untuk Meningkatkan Hasil Belajar Membaca Kritis Paragraf Materi Transportasi Siswa Kelas V SD Negeri 035 Pekanbaru.Jurnal Sorot Volume 10 Nomor 1. 